Western University

Scholarship@Western

FIMS Publications

Information \& Media Studies (FIMS) Faculty

2012

\title{
Open Textbooks and Provincial Government Policy: A Look at the Issues
}

Lisa Di Valentino

The University of Western Ontario, Idivalen@uwo.ca

Follow this and additional works at: https://ir.lib.uwo.ca/fimspub

Part of the Economic Policy Commons, Education Law Commons, Education Policy Commons, Intellectual Property Law Commons, Library and Information Science Commons, $\underline{\text { Public }}$ Economics Commons, and the Public Policy Commons

Citation of this paper:

Di Valentino, Lisa, "Open Textbooks and Provincial Government Policy: A Look at the Issues" (2012). FIMS Publications. 29.

https://ir.lib.uwo.ca/fimspub/29 


\section{Open Textbooks and Provincial Government Policy:}

\section{A Look at the Issues}

\section{Introduction}

In 2012, the British Columbia government announced a plan to fund a program that will result in the creation of open access textbooks for 40 lower-year university courses — the first such program in any of the provinces. This paper will argue that Ontario should follow British Columbia's lead and invest in the development of a project to create and promote the use of open textbooks. The first section will discuss the concept of open textbooks and the various initiatives and legislation that have been introduced in the United States, and British Columbia's plan will be described in more detail. The second section will put forth the reasons that British Columbia's approach is superior to Ontario's current approach to rising textbook prices, addressing such issues as affordability, flexibility in teaching and in learning, and the commodification of information. Section three will address and respond to several concerns and criticisms of government funding of textbook publishing and open textbooks.

\section{Open textbooks and open access initiatives}

The phrase "open access" describes materials (text, image, music, video) that are freely available to anyone who would like to access them (generally on the Internet), and free of most, if not all, copyright restrictions. The material might be in the public domain, or under a public licence such as Creative Commons ("some rights reserved") that allows users to access, download, copy, print, or distribute the content, and in some cases create derivatives or remix it with other content, without further expressed permission of the copyright owner (Harley, Lawrence, Krzys 
Acord, \& Dixson, 2009). It is contrasted with the traditional forms of information dissemination, whereby access may be granted to the user (with or without monetary cost) but certain uses of the material are prohibited without permission of the copyright holder. The ideas underlying open access had been under consideration since at least the mid-1960s, but it was the invention of the World Wide Web in 1991 that led to an organized and expansive open access movement, particularly among academics (Suber, 2009). The Budapest Open Access Initiative of the Open Society Foundation, promoting self-archiving of scholarly research and open access journals, was released in 2002. This was followed in 2003 by the Bethesda Statement on Open Access Publishing, and the Berlin Declaration on Open Access to Knowledge in the Sciences and Humanities initiated by the Max Planck Society.

These initiatives and statements focus primarily on research and literature published in scholarly journals. Their motivation is the idea that scientific and cultural knowledge should be made available to the public. In the past decade there has been a wealth of literature published on the subject of open access to knowledge, and in particular open access scholarly journals, but there has been less written about open textbooks (also known as "open access textbooks" or "open source textbooks") (Morris-Babb \& Henderson, 2012). Given that the open access movement is supported mainly by academics rather than students, this is not surprising. Researchers are interested in new developments in their fields and faculty members are expected to keep up with new findings and contribute to their disciplines through scholarly research.

However, this focus on research over teaching means that there is a knowledge gap with regards to other open access possibilities. It is not sufficient to take the existing literature about open 
access journals and apply it directly to the issue of open textbooks. While both open access journals and open textbooks are based on the ideals of accessibility and affordability, there are fundamental differences between the two types of materials that must be considered. The type of content is not the same: journals publish new research and original theory (or "academic knowledge production" as described by Berg [2012]), while textbooks are tools to teach the fundamentals of a discipline. The audience for scholarly journals are, for the most part, other faculty members or graduate students; textbook end users are generally undergraduate students. Journal articles are written with no expectation of direct financial remuneration on the part of the author or the reviewers, while textbook authors are usually paid royalties from sales. These differences could affect the widespread acceptance and sustainability of an open textbook initiative. On the other hand, an open access format may confer additional advantages over a traditionally published textbook: information can be quickly updated to reflect changes in the field, authors from different institutions can easily collaborate in the creation of a book, and instructors can mix and match resources to individualize the course.

It is important to note that open textbooks are not the same as electronic textbooks, or "etextbooks", such as those offered by companies like Amazon ${ }^{1}$ or textbook publishing companies. While each are accessible online, and generally cost less than the equivalent print textbook, the underlying publishing model of e-textbooks is closer to that of traditional publishing rather than open access. For example, e-textbooks may be available in only one format that can be used only with a certain type of software. Digital rights management ensures that they often cannot be

\footnotetext{
${ }^{1}$ See Amazon's Kindle Textbook at http://www.amazon.com/KindleTextbooks/b?ie=UTF8\&node $=2223210011$.
} 
printed, updated, loaned, or resold, and many are only accessible for a limited period of time (Hilton III \& Wiley, 2010; Morris-Babb \& Henderson, 2012).

In response to the rising prices of traditional textbooks in the U.S., initiatives and campaigns have developed with the aim of easing students' burden of textbook purchases. Student Public Interest Research Groups (Student PIRGs) have initiated a campaign to raise awareness of and promote the use of cost-saving alternatives to traditional publishing, including open textbooks (Harley, Lawrence, Krzys Acord, \& Dixson, 2009). OpenStax ${ }^{2}$, an initiative of Rice University, is funded by foundational grants and offers college-level open textbooks written by educators. The Massachussetts Insitute of Technology offers MIT OpenCourseWare, a suite of open access educational materials including textbooks. ${ }^{3}$ Projects such as the Utah Open Textbook Project, ${ }^{4}$ Connexions, ${ }^{5}$ and Flat World Knowledge ${ }^{6}$ have been established in partnership with universities or government agencies to develop open textbooks. The Ohio Board of Regents (the state agency responsible for evaluating the university system) have partnered with Flat World Knowledge to expand the use of open textbooks in higher education, and to study the impact on student learning ("Board of Regents", 2012). The U.S. Department of Education supplied grant money to the Florida Distance Learning Consortium to study what students look for in order to develop open textbooks (Morris-Babb \& Henderson, 2012).

Some states have enacted legislation aimed at addressing the increasing financial burden of textbooks. In Florida, the Textbook Affordability Act of 2009 requires that a publicly-funded

\footnotetext{
${ }^{2}$ http://openstaxcollege.org/.

3 http://ocw.mit.edu/index.htm.

4 http://utahopentextbooks.org/.

5 http://oerconsortium.org/.

6 http://www.flatworldknowledge.com/.
} 
school has policies to address needs of students who cannot afford textbooks, and requires that the instructor or department relates how a new edition is changed from an earlier edition. California's law directly addresses open textbooks; in 2012 the state legislature passed an amendment to the Education Code that establishes the California Open Education Resources Council, to be responsble for the development of 50 high quality, open source textbooks for use in lower year university courses (SB-1052, 2012). The U.S. federal government has put aside funds for grants to create open source courses for two-year colleges (U. S. Department of Labor, 2011).

By contrast, Canada lags behind in taking up the issue of open textbooks (Coffin, 2012). Athabasca University Press ${ }^{7}$ offers free online access (in PDF format) to some of their titles that are licenced under Creative Commons, but there is no other insitutional effort to develop or promote open textbooks. Open Source Text $\mathrm{Canada}^{8}$ is a registered charity that intends to study the amount schools systems (elementary and high school) could save by moving to open educational resources. There had been, until this year, no action from any of the provincial governments that has addressed the potential of open textbooks.

In October 2012, the government of British Columbia announced that it would be partnering with the province's post-secondary institutions to implement and develop an open textbook policy that will culminate in the creation of Creative Commons-licensed textbooks for 40 firstand second-year university courses ("B. C. to lead", 2012). The project, modeled after

\footnotetext{
${ }^{7}$ http://www.aupress.ca/.

8 http://opensourcetext.ca/.
} 
California's legislation, is to be coordinated by BCCampus, ${ }^{9}$ a publicly-funded organization that investigates and implements technologies in the province's campuses ("BCcampus to coordinate", 2012).

Of the project, John Yap (Minister of Advanced Education, Innovation and Technology) said that the motivation is to increase accessibility and affordability for post-secondary students ("B. C. to lead", 2012). BCCampus will accept proposals for creating the textbooks from faculty, institutions, and publishers.

\section{Should Ontario follow British Columbia's lead?}

Ideally, B. C.'s project will inspire other provinces to follow suit. In taking the opportunity to support the development of open textbooks for its post-secondary students, Ontario would demonstrate leadership in the area of open education.

In its discussion paper Strengthening Ontario's Centres of Creativity, Innovation, and Knowledge, the Ontario Ministry of Training, Colleges \& Universities (2012a) expresses the intention to meet the challenge of transforming education by modernizing the system, and discusses its vision of affordability, innovation, and quality in education. By innovation is meant "those new ideas, systems, and processes that create new learning and teaching modalities, improve learning outcomes, enhance the student experience, and create long-term savings through improved productivity." (pp 8-9) The Ministry acknowledges that online learning represents a major shift in how learning takes place in the 21 st century, and there is a need to respond to and take advantage of new technological opportunities — for example, by offering an

\footnotetext{
${ }^{9}$ http://www.bccampus.ca/.
} 
increased number of online learning modules, and by offering flexible teaching and learning provisions for faculty and students as well as opportunities for collaboration among institutions. Supporting the creation and use of open textbooks will help the province to attain these goals.

\section{Affordability}

Open textbooks would certainly represent an affordable alternative for students. Currently, an undergraduate student can pay up to $\$ 1,000$ per year for traditionally published textbooks (Canadian Press, 2012). The rate of inflation for textbooks is higher than the rate of general inflation (Coffin, 2012); the price of textbooks rose 3.5\% from 2007 to 2008, while total consumer prices rose $0.3 \%$ (Grant, 2008). Several factors contribute to this phenomenon. Unlike most other goods (including other types of books), the primary individuals who choose which textbooks to use (faculty) are not the same individuals who actually pay for them (students) (Apple, 1989; Koch, 2006). Because students do not have the opportunity to choose among competing textbooks of differing cost, and are essentially a "captive buyer" of whatever has been assigned, they are less responsive to price increases (Koch, 2006). This is especially true of firstyear university students, who have not established their own study and learning pattern, and tend to purchase new copies of whatever textbooks are on their reading list. Faculty, for their part, generally place affordability lower on their preference list than factors such as academic quality (Morris-Babb \& Henderson, 2012).

Even when students opt to purchase used textbooks from the bookstore, from fellow students, or from online retailers, it does not result in the lowering of textbook prices in general, or even slow the rate of price increases. While one might assume that it would, since it leads to fewer sales of 
the more expensive new books, it ultimately comes down to the unique nature of the textbook market. There is a substantial initial outlay to put out a textbook of which half the sales occur in the first year after publication. After the first year, sales of new books are "cannibalized" by the used book market (Koch, 2006). Publishers respond to this threat by publishing a "new" edition of the textbook, rendering the "old" edition (and all used copies of it) of reduced utility. As mentioned before, it is faculty rather than students who choose the reading material for a course. A faculty member may or may not have time to compare the two editions to see if there are any substantial changes. The new edition is assigned as a required textbook, and publishers stem the tide of used book sales. Conversely, there may be a need to update the text regularly in fastchanging discipline such as law (Bodie, 2007; Harley, Lawrence, Krzys Acord, \& Dixson, 2009). Nevertheless, the cost to publish a new edition can be far less than the cost of developing an entirely new textbook from scratch, yet the price of the new edition is not less than the price of the first edition.

A third factor that contributes to high textbook prices is bundling of materials (Koch, 2006; Hilton III \& Wiley, 2010). In addition to the textbook proper, there may be workbooks, study guides, CD-ROMs, and passcodes for e-textbooks or other online materials, that double the price of the textbook. An individual student may not have any need for this supplementary material, but as a "captive buyer" the only way she can obtain the textbook is to buy the bundle.

Students will respond in a number of ways to soaring textbook prices: they (or their parents) might simply buy the textbook from the bookstore despite the cost; they might seek out used copies; they might try to manage with an older edition; they might pirate textbooks by 
photocopying or torrenting scanned versions (Wallace, 2009); or they might not buy or obtain any textbook at all. In some cases they might not register for a particular course because of the cost of the reading material (Morris-Babb \& Henderson, 2012).

There is currently no monitoring or regulation of textbook prices in Canada (Bird, 2008). There is also no end in sight to price increases, so the time is ripe to consider a new model. An open textbook model will save students the cost of buying printed textbooks or access to electronic textbooks, or at the very least drastically reduce the cost by allowing them to obtain a printed version for a nominal price.

\section{Flexibility}

Related to the bundling issue, whereby students are forced to buy more material than they might actually use, instructors find that individual textbooks sometimes contain more material than what is needed for the course (Laurence, 2012; Baker, Thierstein, Fletcher, Kaur, \& Emmons, 2009; Hilton III \& Wiley, 2010). Conversely, the textbook might not include certain information they feel is important for the students to learn, so they will supplement textbooks with other materials in order to "customize" the course (Baker, Thierstein, Fletcher, Kaur, \& Emmons, 2009; Harley, Lawrence, Krzys Acord, \& Dixson, 2009). Bodie (2007) calls the casebook (a type of textbook used in law school courses) a "promoter of conformity: it imposes costs on any effort to deviate from it." This cost might be monetary (when students have to buy extra materials), or it might be in the time instructors spend locating them. An open textbook model that incorporates "modules" would allow instructors to mix and match or repurpose content to fit the needs of their course (Laurence, 2002; Bodie, 2007; Coffin, 2012). They can add their own commentary and 
annotations and make them available to the students in the course, or to the public at large (Laurence, 2002). In short, they can have more control over course materials and adapt the readings to suit their teaching needs (Bodie, 2007).

\section{Collaboration and innovation}

The government of Ontario is in a position to support search for or creation of a working, sustainable model for open textbooks in Canada. By taking advantage of the instant communication offered by online communication technologies, authors from geographically dispersed institutions can easily collaborate on the production of an open textbook, or share supplementary materials that they have created for their courses.

\section{Quality}

It is not necessary to sacrifice quality for accessibility and affordability. The characteristics of openness and availability mean that the content of open textbooks can be vetted by faculty and researchers, and immediately improved (Baker, Thierstein, Fletcher, Kaur, \& Emmons, 2009). The interactive nature of particular open textbook models allows for content to be updated whenever necessary for no additional cost.

\section{Knowledge as a public good}

The textbook is not only an economic product, but also a political and cultural good (Apple, 1989). Essentially, it represents the core of a discipline; the very least that a student should know. As with a publicly-assisted education system, the content of this cultural good, and the decision of who should have access to it, must not be reduced to "the bottom line" (Apple, 1989) 
The government has a responsibility to ensure that technological improvements in digital dissemination of information should be used to increase access to core materials, rather than further restrict access, as with digital rights management. While the traditional textbook publishing model may have in the past been the best or most efficient way of creating tools of knowledge transmission, where for-profit publishers were the only ones with the means to mobilize resources (May, 2004), new technologies allow authors to retain control over the products of their intellectual labour instead of ceding it to corporate interests, where editorial decisions are made by those with sales and business backgrounds. (Apple, 1989). There is an opportunity to stem the tide of information commodification in which knowledge is commercialized and capitalized, and regarded as a means of earning profit through restriction rather than a public good that should be available to all (Pyati, 2007).

The government is not innocent in this regard. Since information by its very nature is non-rival and easily circulated, the market can only exist with artificial scarcity (Baker, 2005). Intellectual property law (and contract law) gives the capitalist the right to restrict access to and use of information, a right which is backed up by the state (May, 2004). This right, when possessed by a corporation, represents what Berg (2012) calls “accumulation by disposession". The publishing company profits not only from the labour of the author but also from the copyright, the transfer of which is not strictly necessary for the editorial, printing, and distribution of the textbook, ${ }^{10}$ but which allows them to create unnecessary new editions (Baker, 2005).

Federally, legislature has recognized (at least theoretically) the value of education. In 2012, the Copyright Act was amended to add education to the categories of fair dealing, allowing the

\footnotetext{
${ }^{10}$ A time-limited exclusive licence would accomplish the same end.
} 
limited use of copyrighted materials without monetary remuneration (s. 29). Additionally, a provision was added that permits the reproduction and communication for educational purposes of a work that is freely available on the Internet (s. 30.04(1)). This recognition is theoretical, though, since the new, extremely controversial, provisions respecting non-circumvention of technological protection measures tend to reinforce the notion of information as a commodity (ss. 41ff and throughout).

This inconsistent approach by the federal government makes it all the more necessary for the provinces to take the initiative to protect students' access to knowledge, especially in electronic form. An open textbook undertaking would demonstrate Ontario's leadership and commitment to innovative and accessibile education.

\section{Critiques and concerns}

\section{Government intervention in the market}

Some might be concerned with the very idea of the government involving itself somehow in the market. If the government was not involved in textbook publishing before, what has changed, and why should they be involved now?

As noted above, the cost of textbooks has gone up disproportionately to the rate of general inflation. Students will locate used copies of books via Internet searches of online bookstores, eBay, or book swap forums. It is possible to scan a textbook and offer it for download on a torrent site. While students have always bought used books, shared with colleagues, or photocopied chapters, it was never so easy as with current communication technologies. 
Publishers lament lost sales and further increase the prices of textbooks or publish new editions every year or two, or take advantage of technological protection measures to restrict access or certain uses of electronic content, even where the intended use is permissible under fair dealing or another specific copyright exception.

While Ontario has been offering some relief for students facing rising textbook costs, the province has not yet come up with a sufficient nor efficient solution to the problem. The textbook tax credit of $\$ 65$ per month (as of 2011) is useful to students only after they begin earning taxable income (if they do not transfer it to their parents) (Canada Revenue Agency, 2012). The province had offered a textbook grant of $\$ 150$, but this grant is available only to students who otherwise qualify for the Ontario Student Assistance Program, and the grant was discontinued as of the 2012-2013 year (Ontario Ministry of Training, 2012b).

These reactive (non-)solutions do not address the underlying issue of rising prices. The higher textbook prices go, the more grants and tax credits must be offered to offset the financial burden on students or their parents. The government is essentially using taxpayer money to subsidize the profits of publishing companies. There is no incentive for publishers to lower costs, which could lead to unnecessary, inefficient public spending.

Furthermore, as noted earlier, the government already grants publishers a monopoly in the form of intellectual property, allowing publishers a form of control over the textbook market that does not exist in markets for other goods (except pharmaceuticals). In addition to granting the usual exclusive rights afforded by copyright protection — reproduction, display, translation, adaptation, etc. — the Copyright Act forbids parallel importation of copies of non-used textbooks 
from a foreign country (s. 27.1), further subsidizing publishers by preventing the purchase of textbooks from certain sellers who may offer lower prices. ${ }^{11}$

It is clear, then, that the government is already intimately involved in the textbook market in the role of supporter (with public funding) and enforcer.

The alternative, supporting the creation of open textbooks or open textbook initiatives, is a superior approach. The British Columbia project is expected to cost between $\$ 600,000$ and $\$ 1,000,000$ per year ("B. C. to offer", 2012), but this must be balanced against the savings that will incur from the elimination of grants and tax credits. If Ontario is planning to create 60,000 more places for post-secondary students (Ontario Ministry of Training, 2012a), support for students in the form of individual financial aid will need to increase accordingly. By contrast, open textbooks, by their very nature, are shared goods, and the cost of producing them does not significantly increase by the addition of more users.

Furthermore, Ontario's after-the-fact approaches, such as they are, do not address openness and accessibility issues, or the concern of increased information commodification. On the contrary, they encourage information commodification by providing public funds that incentivize profitmaking endeavours, which may not confer any additional advantage on the ultimate purchaser of the commodity (the student). Governments have already inserted themselves into the sphere of

\footnotetext{
${ }^{11}$ Technically, then, it is an infringement of copyright to purchase new books from American retailers such as Amazon.com, if the books are available for sale in Canada.
} 
post-secondary education by investing in colleges and universities; ${ }^{12}$ there seems to be no reason that they should not likewise support the creation of textbooks.

A related concern is that government support of open textbook initiatives represents unfair competition in the publishing business, or there would be an unfair advantage with regards to public domain or publicly-licenced books. The initial response to such a critique is to reiterate that the government already provides certain unique advantages to textbook publishers in the form of copyright monopolies and profit subsidization through student financial aid.

Furthermore, the use of open textbooks does not have to be mandated; it is not a given that instructors would choose an open textbook over a traditional all-rights-reserved textbook. ${ }^{13}$ Alternatively, the government might allocate funds to existing traditional publishers to develop and publish textbooks that would be offered to the public domain or under a public licence (Baker, 2005). Indeed, British Columbia’s Request for Proposals invites publishers to submit implementation plans (“BC Campus to co-ordinate”, 2012).

Other commentators have worried that the content of government-funded textbooks will reflect government interests, but this fear is unfounded. There is no reason to think that the content of open textbooks would be any different from what would be found in a proprietary textbook. The faculty who write them or assign them would still be protected by the usual academic freedoms that they enjoy working in government-funded institutions. In fact, modular open textbooks

\footnotetext{
${ }^{12}$ In 2008-2009, over $50 \%$ of university revenues in Ontario came from government sources (Canadian Education Statistics Council, 2011).

${ }^{13}$ One would hope, however, that increased awareness of open textbooks would lead students to encourage faculty to strongly consider their use.
} 
promote academic freedom as they allow instructors to easily adapt curriculum rather than relying on one author's work, or supplementary materials.

\section{Model sustainability}

Once a government-funded open textbook project is initiated, how will it be financially sustained in the long term? Or will taxpayers continue to further subsidize those who choose to obtain a post-secondary education? This concern is a valid one and requires to be addressed.

It should be pointed out that costs are generally far lower for digital textbooks than in traditional publishing because the content is delivered online, and can be easily updated with no need for additional print runs. Students who prefer a physical copy would be able to print one themselves, or order one from the publisher or a print-on-demand service for a nominal cost that covers printing, binding, and shipping.

Existing open textbook projects employ a variety of business models that could be considered, alone or in combination. Flat World Knowledge (FWK) uses what they call a "freemium" model. Users are given free access to the online text under a Creative Commons licence, while PDF and printed versions are available at a cost that would be significantly lower than that of an equivalent traditional printed textbook (Hilton III \& Wiley, 2010). There are also study guides and online quizzes that are available for a free either individually or in bundles. Authors receive a $20 \%$ royalty from sales of these materials. (Note, however, that this business model has not been particularly successful for FWK, and they are now moving to a fully paid model with various fee structures [Flat World Knowledge, n. d.].) 
OpenStax is funded by grants from various foundations, including the Bill and Melinda Gates Foundation and Rice University, and allows for donations. This is similar to the Wikipedia model, which relies mainly on donations. ${ }^{14}$ Connexions is also funded by foundations and institutions, and a consortium made up of members from the for-profit and not-for-profit sectors around the world (including Creative Commons and Teachers Without Borders).

Alternatively, public funds could be used to endow a startup project, and from there universities could take over by incentivizing the creation and use of open textbooks (discussed further below).

These projects and initiatives are relatively new, certainly newer than the traditional textbook publishing model, and as time passes it will become apparent which business models work and which do not. In the meantime, the provincial government could at least begin contributing directly to research on the subject by funding a study on open textbook business models.

\section{Quality and innovation}

Textbooks do not appear out of thin air; they must be written by authors who are well-versed in the discipline. The academics who write textbooks are employed at post-secondary institutions, and must balance this endeavour with teaching, supervision, research, grant applications, and committee responsibilities. Junior faculty who are working towards earning tenure credits are often advised by senior faculty to forego textbook authorship for "worthier" pursuits such as research, which are viewed more favourably by tenure committees (Bodie, 2007; Morris-Babb \&

\footnotetext{
${ }^{14}$ For the 2011-2012 fiscal year, 91\% of Wikimedia's revenue came from donations (Wikimedia Foundation, 2012).
} 
Henderson, 2012). Textbooks require a large outlay of time and energy and are generally not considered novel contributions to the literature and thus do not "count" towards a faculty member's academic curriculum vitae (Bodie, 2007). Peter Atkins, author of the influential textbook Physical Chemistry, said that "it is increasingly difficult for publishers to get people to write textbooks. Heads of department are adamant that their faculty members focus on research, so publishers are finding it difficult to commission people of the quality they need." (Jones, 2010) Textbook output does not factor into the rankings of post-secondary institutions, but research output does.

Some authors may write a textbook because they would like to reach a wider audience, and they are dissatisfied with the existing textbooks. Many more write textbooks in order to earn royalties from sales. Open textbooks do not promise the kinds of royalties that an author may earn from a proprietary textbook. Without a financial incentive, and without the promise of academic recognition, it appears as though it would be difficult to find authors to dedicate themselves to such a project, and there would be no (new) textbooks.

It could also be argued that the low cost and ease of online publishing will lead to a flood of inferior textbooks (Pettigrew, 2012). Profit acts as the "gatekeeper"; publishers want a return on investment so they will only publish that which is "good" and thus likely to sell (or likely to sell and thus "good"). If anyone can publish, it would be near impossible to separate the wheat from the chaff.

As already noted, several authors can collaborate on an open textbook far easier than they could in a traditional publishing environment (Bodie, 2007). This allows the workload to be divided. 
Different modules of the textbook could be written by different authors and cleaned up by an editor. Because the resulting open textbook is freely available, as a whole or as a collection of separate modules, each author's contribution has a potential to be widely seen (Bodie, 2007).

This openness and availability also means that the content can be vetted by other faculty and researchers, and immediately corrected or improved if necessary (Baker, Thierstein, Fletcher, Kaur, \& Emmons, 2009). Other suggestions include the provision of review and editorial oversight by disciplinary associations (Harley, Lawrence, Krzys Acord, \& Dixson, 2009), or support for open textbook authors from academic institutions in the form of paid leave, tenure points, academic credit, editorial support, grants, or monetary prizes for the best-received textbooks (Harley, Lawrence, Krzys Acord, \& Dixson, 2009; Morris-Babb \& Henderson, 2012).

\section{Copyright}

If an open textbook is intended to include material from other copyrighted sources, it is important to consider whether such as use is permissible within a work that itself is free of most copyright restrictions. While disciplines such as law draw material from sources that are not under copyright (as in the case of U.S. legislation and trial decisions), or licenced for noncommerical use (Canadian legislation and trial decisions), the same cannot necessarily be said for other fields. Pettigrew (2012) notes that humanities textbooks often include content by other authors under a copyright licence. Creators of an open textbook on the subject of, for example, poetry, or literary criticism, would need to secure permission to reproduce the works of others. Such permission would likely not be forthcoming, and if it were, it would come with a financial cost. Whether the reproduction of these materials would fall under the fair dealing exception is 
not clear. The ultimate purpose of the use is education (or criticism), which is an enumerated fair dealing category, but there are other factors to consider. The Canadian Supreme Court decision CCH Canadian Ltd. v. Law Society of Upper Canada (2004) includes among these factors the character of the dealing: "if multiple copies of the works are being widely distributed, this will tend to be unfair." (para. 55) Given that an open textbook is intended to be widely accessible, it would appear to represent exactly the sort of dealing the Court is warning against.

A solution to this problem might be to omit the copyrighted content altogether, but include a link to it if it is available elsewhere on the Internet, as hyperlinking is not a violation of copyright, per the Federal Court decision Warman v. Fournier (2012). In any case, more analysis will be needed to determine the permissibility of reproduction in these situations. In most other situations, however, copyrighted content is not necessary and so the problem does not arise.

A second issue arises with the use of Creative Commons licences. ${ }^{15}$ These licences come in a variety of permutations, not all of which are compatible with each other. For example, the CCBY-SA (attribution, share alike) licence, which is used by Wikipedia, requires that any downstream user of the material use the same licence for any works that are created with it. If an open textbook were to incorporate material from Wikipedia, the whole textbook must share that licence. It would not do to specify that any use of the textbook is restricted to non-commercial dealings (CC-BY-NC) or that derivatives cannot be made (CC-BY-NC). This might pose a problem when taking advantage of the "mix and match" flexibility of the open textbook model, if different textbooks carry different licences. Under a modular approach these difficulties could be

\footnotetext{
${ }^{15}$ http://creativecommons.org/licenses/.
} 
avoided, since the book can be split into separate sections, and is not necessary that all sections are offered under the same licence.

The suggestion has been made that open textbooks (at least those created with the help of government funds) should not carry any copyright at all and fall immediately into the public domain (Baker, 2005). This approach would avoid the issue of incompatible licences, but raises concerns of its own. For example, it is not necessary to give attribution to the author(s) of a public domain work, whereas a Creative Commons licence demands it. Without this requirement, it might be difficult to attract authors who are willing to give up royalties and tenure credit but would like at the very least be credited for their work.

\section{Conclusion}

It is imperative that the issue of textbook inflation be addressed in some way by the provincial government. Left to their own devices, publishing companies will take advantage of their copyright monopolies by continuing to raise prices and employ technology to restrict availability and use in order to maximize profit. Ontario must ensure that all students (and all citizens) have access to high quality educational tools and that new technologies are used to bring us towards this goal, not away from it. The current reactive scheme of grants and tax credits does not address the fundamental issues at play and encourages commercial publishers to continue to seek ever higher profits on the backs of the taxpayers. This money would be put to better use proactively in developing an open textbook program that is not only more economical, but that represents the value of knowledge and information in education as public goods, rather than private property. 


\section{Bibliography}

Albert, K. M. (2006). Open access: Implications for scholarly publishing and medical libraries. Journal of the Medical Library Association, 94(3), 253-262.

Alberta (Education) v. Canadian Copyright Licensing Agency (Access Copyright), 2012 SCC 37. Retrieved from http://canlii.ca/t/fs0v5.

Apple, M. A. (1989). Textbook publishing: The political and economic influences. Theory into Practice, 28(4), 282-287.

B. C. to lead Canada in offering students free, open textbooks (news release). (2012, October 16). Government of British Columbia. Retrieved from http://www.newsroom.gov.bc.ca/2012/10/bc-to-lead-canada-in-offering-students-freeopen-textbooks.html.

B. C. to offer free textbooks online. (2012, October 16). CBC News. Retrieved from http://www.cbc.ca/news/canada/british-columbia/story/2012/10/16/bc-onlinetextbooks.html.

Baker, D. (2005, September). Are copyrights a textbook scam? Alternatives to financing textbook production in the 21 st century. Washington, D. C.: Center for Economic and Policy Research. Retrieved from http://www.cepr.net/index.php/publications/reports/arecopyrights-a-textbook-scam-alternatives-for-financing-textbook-production-in-the-21stcentury/.

Baker, J., Thierstein, J., Fletcher, K., Kaur, M., \& Emmons, J. (2009). Open textbook proof-ofconcept via Connexions. International Review of Research in Open and Distance Learning, 10(5), 1-13. Retrieved from http://www.irrodl.org/index.php/irrodl/article/view/633/1387.

BCcampus to co-ordinate provincial open textbook project (blog post). (2012, October 16). BCCampus. Retrieved from http://www.bccampus.ca/bccampus-to-co-ordinateprovincial-open-textbook-project/.

Berg, L. D. (2012). Knowledge enclosure, accumulation by dispossession, and the academic publishing industry (guest editorial). Political Geography, 31, 260-262.

Berlin Declaration on Open Access to Knowledge in the Sciences and Humanities. (2003, October 22). Max Planck Society. Retrieved from http://oa.mpg.de/lang/en-uk/berlinprozess/.

Bethesda Statement on Open Access Publishing. (2003, June 20). Retrieved from http://www.earlham.edu/ peters/fos/bethesda.htm. 
Bill C-11, An Act to amend the Copyright Act, 1st Sess., 41st Parl., 2011 (assented to 29 June 2012), S.C. 2012, c. 20. Retrieved from http://www.parl.gc.ca/content/hoc/Bills/411/Government/C-11/C-11_4/C-11_4.PDF.

Bird, J. (2008, September 6). A textbook case of sky-high prices. The Ottawa Citizen. Retrieved from http://www.canada.com/ottawacitizen/news/city/story.html?id=c28b9b6a-8f1348e6-8622-d8b99100cf5f.

Board of Regents and Flat World Knowledge announce textbook program extension (news release). (2012, June 7). Retrieved from https://www.ohiohighered.org/press/boardregents-and-flat-world-knowledge-announce-textbook-program-extension.

Bodie, M. (2007). The future of the casebook: An argument for an open-source approach. Journal of Legal Education, 57(1), 10-35. Retrieved from http://ssrn.com/abstract=691985.

Budapest Open Access Initiative. (2002, February 14). Open Society Foundations. Retrieved from http://www.opensocietyfoundations.org/openaccess/read.

Canada Revenue Agency. (2012). Textbook amount (web page). Retrieved from http://www.craarc.gc.ca/tx/ndvdls/tpcs/ncm-tx/rtrn/cmpltng/ddctns/lns300-350/323/txtbk-eng.html.

Canadian Education Statistics Council. (2011, June). Spending on postsecondary education. Retrieved from http://www.statcan.gc.ca/pub/81-599-x/81-599-x2011007-eng.pdf.

Canadian Press. (2012, September 23). Art textbook with blank pages cost Ont. students \$180. CBC News. Retrieved from http://www.cbc.ca/news/canada/toronto/story/2012/09/23/toronto-ocad-art-textbookcost.html.

CCH Canadian Ltd. v. Law Society of Upper Canada, 2004 SCC 13, [2004] 1 S.C.R. 339. Retrieved from http://canlii.ca/t/1glp0.

Coffin, M. (2012) Canada's contribution to the commons: Creating a culture of open education. Edmonton: Athabasca University Graduate Students' Association. Retrieved from http://www.augsa.com/media_files/PDFs/reports/20120914\%20-\%20augsa\%20\%20open\%20education\%20canada.pdf.

Copyright Act, R.S.C. 1985, c. C-42. Retrieved from http://canlii.ca/t/hz9m.

Flat World Knowledge. (n. d.). Why Flat World is moving from free to fair on January 1, 2013. Retrieved from http://www.flatworldknowledge.com/free2fair.

Grant, T. (2008, September 29). Inflation 101: Students get tough lesson on tuition, textbooks. The Globe and Mail. Retrieved from http://www.theglobeandmail.com/report-on- 
business/economy/economy-lab/inflation-101-students-get-tough-lesson-on-tuitiontextbooks/article4327431/.

Harley, D., Lawrence, S., Krzys Acord, S., \& Dixson, J. (2009, October). Affordable and open textbooks: An exploratory study of faculty attitudes. Research \& Occasional Paper Series (CSHE.9.09). University of California, Berkeley. Retrieved from http://cshe.berkeley.edu/publications/publications.php?id=342.

Hilton III, J. L., \& Wiley, D. A. (2010). A sustainable future for open textbooks? The Flat World Knowledge story. First Monday, 15(8). Retrieved from http://firstmonday.org/htbin/cgiwrap/bin/ojs/index.php/fm/article/view/2800/2578.

Jones, N. (2010, February 4). Q\&A: Peter Atkins on writing textbooks. Nature, 463.

Katz, A. (2012, September 19). Copyright Board: Category 4 copies are fair dealing (blog post). Retrieved from http://arielkatz.ca/?p=2022.

Keller, J. (2011). Publishers criticize federal investment in open educational resources. Retrieved October 30, 2012, from http://chronicle.com/blogs/wiredcampus/publisherscriticize-federal-investment-in-open-educational-resources/31483.

Klassen, T. (2012, October 23). A closer look at B.C.'s open textbook plan. Macleans. Retrieved October 30, 2012, from http://oncampus.macleans.ca/education/2012/10/23/a-closerlook-at-b-c-s-open-textbook-plan/.

Koch, J. V. (2006, September). An economic analysis of textbook pricing and textbook markets. Advisory Committee on Student Financial Assistance. Retrieved from https://www.wvhepc.org/commission/Textbooks\%20Study/ACSFA\%20College\%20Text book\%20Cost $\% 20$ Study\%20Plan\%20Proposal.pdf.

Laurence, R. (2002). Casebooks are toast. Seattle University Law Review, 26(1), 1-11.

May, C. (2004). Commodifying the "information age": Intellectual property rights, the state and the Internet. SCRIPT-ed, 1(3), 409-419. Retrieved from http://eprints.lancs.ac.uk/35532/.

Morris-Babb, M., \& Henderson, S. (2012). An experiment in open-access textbook publishing: Changing the world one textbook at a time. Journal of Scholarly Publishing, 43(2), 148155.

Ontario Ministry of Training, Colleges \& Universities. (2012a). Strengthening Ontario's centres of creativity, innovation and knowledge. Retrieved from http://www.tcu.gov.on.ca/pepg/publications/DiscussionStrengtheningOntarioPSE.pdf.

Ontario Ministry of Training, Colleges and Universities. (2012b). Textbook and technology grant (web page). Retrieved from https://osap.gov.on.ca/OSAPPortal/en/AZListofAid/PRD003559.html. 
Pettigrew, T. (2012, October 2). B.C.'s free textbooks plan needs a closer look. Macleans. Retrieved October 30, 2012, from http://oncampus.macleans.ca/education/2012/10/22/bc-s-free-textbooks-plan-needs-a-closer-look/.

Pyati, A. (2007). A critical theory of open access: Libraries and electronic publishing. First Monday, 12(10). Retrieved from http://firstmonday.org/htbin/cgiwrap/bin/ojs/index.php/fm/article/viewArticle/1970/1845.

SB-1052: Public postsecondary education: California Open Education Resources Council. (20112012). Retrieved from http://leginfo.legislature.ca.gov/faces/billNavClient.xhtml?bill_id=201120120SB1052.

Suber, P. (2009, February 9). Timeline of the open access movement (web page). Retrieved from http://www.earlham.edu/ peters/fos/timeline.htm.

Suber, P. (2012, October 27). Open access overview (web page). Retrieved from http://www.earlham.edu/ peters/fos/overview.htm.

U. S. Department of Labor (2011, January 20). Notice of availability of funds and solicitation for grant applications for trade adjustment assistance community college and career training grants program. Retrieved from http://www.doleta.gov/grants/pdf/SGA-DFA-PY-1003.pdf.

Warman v. Fournier, 2012 FC 803. Retrieved from http://canlii.ca/t/fs2s2.

Wikimedia Foundation. (2012). Annual report. Retrieved from http://meta.wikimedia.org/wiki/Wikimedia_Foundation/Annual_Report/20112012/Single. 